\title{
Reproductive Characteristics of the Ocelot (Leopardus pardalis)under Captive Conditions
}

\author{
Dana Havlanová ${ }^{1}$, Ivana Gardiánová ${ }^{2, *}$ \\ ${ }^{1}$ Graduate of Special Animal Raising, FAFNR, Czech University of Life Sciences in Prague, Czech Republic; Havlan's Ocelot Caterry \\ ${ }^{2}$ Demonstrational and Experimental Workplace, FAFNR, Czech University of Life Sciences in Prague, Czech Republic \\ *Corresponding Author: gardianova@af.czu.cz
}

Copyright (C) 2013 Horizon Research Publishing All rights reserved.

\begin{abstract}
The ocelot Leopardus pardalis is one of the beautifully colored cats of family Felidae. Their successful reproduction undercaptive conditions are not very high. We studied the reproductive characteristics of ocelots from 1960 to 2010 . The aim of study was to investigate the reproductive success of ocelots between continents. The following results were found: all continents: 139 captive females produced 576 litters with a total of 752 kittens of which 545 were successfully raised to adulthood. The number of successfully raised males was 295 compared to 250 females. Eighty-six were of unidentified sex. About 359 individuals were reared by the mother and 108 hand reared. Of the total births, 416 were single kittens, 146 were twins, 12 were triplets and two were quadruplets. Females had their first litter at a mean age of 4.2 years old and had a mean of four litters during her live. The mean number of kittens per female was 5.4 kittens, of which 3.9 were successfully reared. Comparison between continent - in America and Europe were born more than 350 kittens, in Asia 50. Reared were 278 kittens in America, 226 in Europe and 41 in Asia. Only some kittens were hand reared. Globally, the highest number of litters occurred during June and August, while the lowest number occurred during November and December. It was found that before 1990, most successful rearings were kittens raised by the mother butafter 1990, the most successful rearings were hand reared kittens.
\end{abstract}

Keywords Ocelot, Reproduction, Captive Conditions

\section{Introduction}

The ocelot Leopardus pardalis, also called "tigrillo", belongs to the beautifully colored and marked family Felidae. The ocelot is widely distributed from Mexico through Central and South America south to NE Argentina and southern Brazil and Uruguay, found in every country except Chile. Only a small remnant population is found north of the Rio Grande in the United States [21]. Ocelot territory and population numbers have been decreased and are substantially influenced by the continuous deforestation, clearing and destruction of their habitat [8]. The species occupies a wide spectrum of habitats including mangrove forests and coastal marshes, savanna grasslands and pastures, thorn scrub, and tropical forest of all types (primary, secondary, evergreen, seasonal and montane, although it typically occurs at elevations below $1200 \mathrm{~m}$ )[19]. Ocelots have been caught and bred as pets. Therefore the ocelot Leopardus pardalis, as well as most of the small Felidae family is in the Red Book list of endangered species, IUCN [2].Reproduction in captivity is complex and only $71 \%$ of males and $75 \%$ of females able to reproduce. Of the females that have given birth to live young in captivity, only $63 \%$ were able to care for their young after birth. Often not only exotic cats are maternal instincts worst with the first litter. Under captive conditions it often happens that the female, being nervous and restless with her litter, kills the kittens or stops care [22]. The ocelots are able to reproduce all year [18[.In wild populations [12] observed,15 adult females gave birth from the middle of April to late December. According to [3] ocelots in the Yucatan in Mexico for the most part mated in October and delivered in January, and ocelots in Argentina delivered from October to January in wild. On the contrary, [21] observed that in Texas, ocelots born in the wild delivered in late summer and autumn. [3, 14], states, that the number of young in a litter is small, usually one rather, than two young and only sporadically three. [7, 16] found from one to three kittens in 168 litters of ocelots under captive conditions, of which triplets were born in three of the litters Only one known case of a quadruplet birth has been recorded [12].

\section{Material and Methods}

The zoological gardens and private breeders in Czech Republic, as well as zoos in Europe, Asia and North America, were contacted to obtain dataon ocelot reproduction under captive conditions. Data obtained was from 1965 to 2010. The data were from 21 zoos in Europe, 7 Czech private breeders, 2 zoos from Asia and 73 zoos from America. The 
following data was available: kitten birthrate,number reared (to adulthood),mortality rate (all/males/females), number of unidentified gender, number of litters, mother reared,hand reared,unknown reared, the females age atbirth of first litter. For data evaluation we used SAS 9.2@ Mean procedure. The ANOVA - GLM procedure was used as well as the nonparametric Kruskal-Walis test to detect statistically significant differences of observed characteristics of reproduction. Statistical differences of characteristics were at $P \leq 0.05$.

\section{Results}

\section{Evaluation of the reproduction of ocelots}

Data from the European and Asiatic zoos and from the North America Studbook, showed the following: from 1965 - 2010, 139 captive females had 576 litters with a total of 752 kittens of which 545 were reared. 295 were males, 250the successfully reared kittens females (to adulthood) and 87 of them had unidentified gender.About 359 individuals were mother reared and next 108 were handreared. 416 were single births, 146 were twins, 12 triplets and 2 quadruplets of total births. The highest number of kittens per litter was $1-2$. The female's average age for her first litter was 4.2 years and the number of litters per female was around 4. Comparisons between females from different continents (Table 1,2) were investigated. The statistical differences of reproduction characteristics per female - comparison among Asia, Europe and North America were detected in reared kittens/males per female, mother reared per female and by twins.Most of the twins were born in North America 70, in Europe 61, in Asia 15(table 1,2).

In Asia31 litters produced 50 kittens, 9 died and 41 were successfully reared. In Europe, both in zoos and in private breeding programs, the meanage of females at their first litter was 3.4 years ( 1241 days).

In North America 87 females gave birth to 298 litters with a total of 378 kittens. Of these 278 were successfully reared while 100 died.176 were males, 152 were females and 50 were kittens of unidentified sex. In North America $42 \%$ were reared by the mother, $30 \%$, were hand reared, $28 \%$ were unidentified rearing. The number of hand reared $30 \%$ (83) was the highest of all analyzed continents. Incidence of birth in America: singles 223, twins 70; triplets 5.
Table 1. Reproductive characteristics of captive ocelots between continents from 1965 - 2010comparison among Asia, Europe and North America and together (number)

\begin{tabular}{|c|c|c|c|c|}
\hline Reproduction characteristics & Asia & Europe & N. America & Total \\
\hline number of litters & 31 & 247 & 298 & 576 \\
\hline Number of kittens born & 50 & 324 & 378 & 752 \\
\hline Number of male kittens born & 23 & 158 & 176 & 357 \\
\hline $\begin{array}{l}\text { Number of female kittens } \\
\text { born }\end{array}$ & 22 & 134 & 152 & 308 \\
\hline Number of kitten mortalities & 9 & 98 & 100 & 207 \\
\hline $\begin{array}{l}\text { Number of male kitten } \\
\text { mortalities }\end{array}$ & 1 & 33 & 28 & 62 \\
\hline $\begin{array}{l}\text { Number of female kitten } \\
\text { mortalities }\end{array}$ & 3 & 33 & 22 & 58 \\
\hline $\begin{array}{l}\text { Number of kittens } \\
\text { successfully reared }\end{array}$ & 41 & 226 & 278 & 545 \\
\hline $\begin{array}{l}\text { Number of males reared } \\
\text { successfully }\end{array}$ & 22 & 125 & 148 & 295 \\
\hline $\begin{array}{l}\text { Number of females reared } \\
\text { successfully }\end{array}$ & 19 & 101 & 130 & 250 \\
\hline $\begin{array}{l}\text { Number of kittens: } \\
\text { unidentified sex }\end{array}$ & 5 & 32 & 50 & 87 \\
\hline $\begin{array}{l}\text { Number of kittens mother } \\
\text { reared }\end{array}$ & 41 & 201 & 117 & 359 \\
\hline $\begin{array}{l}\text { Number of kittens hand } \\
\text { reared }\end{array}$ & 0 & 25 & 83 & 108 \\
\hline $\begin{array}{l}\text { Number of unknown rearing } \\
\text { method }\end{array}$ & 0 & 0 & 78 & 78 \\
\hline one young in litter & 14 & 179 & 223 & 416 \\
\hline number of litters with twins & 15 & 61 & 70 & 146 \\
\hline number litters with triplets & 2 & 5 & 5 & 12 \\
\hline $\begin{array}{l}\text { number of litters with } \\
\text { quadruplets }\end{array}$ & 0 & 2 & 0 & 2 \\
\hline
\end{tabular}

Following are the degrees of frequency: one kitten per litters about $62 \%$, twins about $37 \%$,triplets about $1 \%$. Data collected and evaluated by author of this study were similar in all continents one kitten per of litter in $72.2 \%$; twins, $25.3 \%$; triplets $2.1 \%$. When comparing these data, it is evident that there are similar births and smaller litters in captive conditions than in the wild. When comparing the number of live births of males and females from Asia, Europe and North America, the sex ratio was 1.6:1 favor for males.

Average each female had 5.4 kittens and 3.9 were successfully reared (see Table 2). 
Table 2. Reproductive characteristics of ocelots per female (Mean, SD and CV) - comparison among Asia, Europe and North America (*statistical difference at $\mathrm{P} \leq 0.05$ ) and together

\begin{tabular}{|c|c|c|c|c|c|c|c|c|c|c|c|c|}
\hline \multirow[b]{2}{*}{ reproduction characteristics } & \multicolumn{3}{|c|}{ all $(\mathrm{n}=139)$} & \multicolumn{3}{|c|}{ Asia $(n=6)$} & \multicolumn{3}{|c|}{ America $(\mathrm{n}=47)$} & \multicolumn{3}{|c|}{ Europe $(n=86)$} \\
\hline & $\bar{x}$ & SD & $\mathrm{CV}$ & $\bar{x}$ & $\mathrm{SD}$ & $\mathrm{CV}$ & $\bar{x}$ & $\mathrm{SD}$ & $\mathrm{CV}$ & $\bar{x}$ & SD & $\mathrm{CV}$ \\
\hline born kittens per female & 5.4 & 4.7 & 86.7 & 8.3 & 7.7 & 92.2 & 4.4 & 3.6 & 81.5 & 6.8 & 5.5 & 80.3 \\
\hline reared kittens per female* & 3.9 & 3.5 & 87.7 & $6.3^{*}$ & 5.4 & 85.7 & $3.3^{*}$ & 2.9 & 88.5 & $4.8^{*}$ & 3.8 & 79.6 \\
\hline mortality kittens per female & 1.5 & 2.4 & 162.0 & 2 & 3.1 & 154.9 & 1.1 & 1.7 & 152.2 & 2.1 & 3.2 & 153.7 \\
\hline born males per female & 2.6 & 2.3 & 90.9 & 3.8 & 3.1 & 81.5 & 2.1 & 1.9 & 94.3 & 3.3 & 2.6 & 79.4 \\
\hline reared males per female* & 2.1 & 1.9 & 93.8 & $2.6^{*}$ & 2.1 & 79.8 & $1.7^{*}$ & 1.7 & 97.8 & $2.7^{*}$ & 2.2 & 84.2 \\
\hline mortality males per female & 0.4 & 0.9 & 205.5 & 0.2 & 0.4 & 223.6 & 0.3 & 0.6 & 196.8 & 0.3 & 1.2 & 188.9 \\
\hline born female per female & 2.2 & 2.3 & 106.4 & 3.7 & 4.8 & 130.9 & 1.8 & 1.6 & 92.9 & 2.8 & 2.8 & 100.6 \\
\hline reared females per female & 1.8 & 1.8 & 102.9 & 1.8 & 1.6 & 91.3 & 1.5 & 1.6 & 107.8 & 2.1 & 2.0 & 94.8 \\
\hline mortality per female & 0.4 & 0.9 & 246.4 & 0 & 0 & 0 & 0.3 & 0.6 & 233.7 & 0.7 & 1.4 & 207.9 \\
\hline unidentified gender per female & 0.6 & 1.4 & 204.4 & 1 & 2.2 & 223.6 & 0.6 & 1.2 & 209.2 & 0.7 & 1.4 & 194.9 \\
\hline litters per female & 4.1 & 3.4 & 81.6 & 5.2 & 4.8 & 93.6 & 3.4 & 2.6 & 75.9 & 5.2 & 4.1 & 77.6 \\
\hline mother reared per female* & 2,5 & 3.3 & 130.6 & $6.3^{*}$ & 5.4 & 85.7 & $1.4^{*}$ & 1.9 & 143.9 & $4.2 *$ & 2.2 & 229.2 \\
\hline unknown reared per female & 0.8 & 1.8 & 301.2 & 0 & 0 & 0 & 4.8 & 2.2 & 229.2 & 0 & 0 & 0 \\
\hline 1 young per female & 4.2 & 2.8 & 92.7 & 2.3 & 2.2 & 92.6 & 2.5 & 2.3 & 88.4 & 3.9 & 3.5 & 89.0 \\
\hline twins per female* & 3 & 1.4 & 135.7 & $2.5^{*}$ & 2.9 & 115.2 & $0.1^{*}$ & 1.1 & 132.6 & $1.3^{*}$ & 1.6 & 124.8 \\
\hline triplets per female & 1 & 0.4 & 458.0 & 0.3 & 0.8 & 244.9 & 0.1 & 0.4 & 610.8 & 0.1 & 0.3 & 331.4 \\
\hline quadraplets per female & 0.1 & 0.2 & 1178.9 & 0 & 0 & 0 & 0 & 0 & 0 & 0.1 & 0.3 & 682.6 \\
\hline
\end{tabular}


Comparing the number of litters by months of the year

When evaluating the number of litters by month, the highest number occurred in June and August, while the lowest number was noted in November and December. In May there were $55(10 \%)$ litters, June $60(11 \%)$ and August 73 (13\%). Conversely, the smallest number of litters was realized in November, with a total of 11 litters and in December with 33 litters. The most "prolific" months were May, June and August. The percentages were similar - May and June both $10 \%$ and August $15 \%$. The lowest number was in the winter, November and December $-6 \%$. These data correspond to the data published in the Studbook of North America [1]. According to both results and the Studbook, we can confirm the hypothesis that seasonality affects the number of litters. When comparing the data of litters in Europe with the data by [1] in the Studbook of North America, we can see the difference in November, Evaluation the ratio is 5:8 for Europe. Data are presented in Tables 3 .

There was a trend towards an decrease in ocelot populations in captivity between 1960 and 2010. During these past two decades successful breeding as well as hand rearing of the species has increased (Table 4). From 1960 do 1999 increased number of born and reared kittens, in litter were 1 young and twins.Better reproduction ability [rearing, number of animals] is in the wild.

You can also discuss why there is such a difference between countries - is it number of females available for breeding or are there other factors involved? - The differences between countries can by the number of available females, some zoos have only very young or old animals, some zoos have ocelots as exposition and no for reproduction.

Table 3. The number and percentage of litters between months in Asia, Europe, North America

\begin{tabular}{llllllll}
\hline & Asia & \multicolumn{5}{c}{ Europe } & \multicolumn{2}{c}{ N. America } \\
\cline { 2 - 7 } Month & $\Sigma$ & $\%$ & $\sum$ & $\%$ & $\sum$ & $\%$ & $\Sigma$ \\
\hline January & 1 & 3 & 19 & 8 & 23 & 8 & 43 \\
February & 3 & 10 & 17 & 7 & 22 & 7 & 42 \\
March & 5 & 16 & 11 & 5 & 28 & 9 & 44 \\
April & 7 & 24 & 16 & 7 & 20 & 7 & 43 \\
May & 6 & 19 & 22 & 10 & 27 & 9 & 55 \\
June & 3 & 10 & 29 & 13 & 28 & 9 & 60 \\
July & 1 & 3 & 19 & 8 & 26 & 9 & 46 \\
August & 1 & 3 & 27 & 12 & 45 & 16 & 73 \\
September & 1 & 3 & 19 & 8 & 27 & 9 & 47 \\
October & 2 & 6 & 17 & 7 & 21 & 7 & 40 \\
November & 1 & 3 & 18 & 8 & 12 & 4 & 31 \\
$\begin{array}{l}\text { December } \\
\text { Total number }\end{array}$ & 0 & 0 & 17 & 7 & 18 & 6 & 35 \\
of litters & 31 & & 247 & & 298 & & \\
\hline
\end{tabular}


Table 4. Reproduction trends in decades

\begin{tabular}{|c|c|c|c|c|c|c|c|c|c|c|c|c|c|c|c|c|c|c|c|c|}
\hline \multirow[b]{2}{*}{ Trend of reproduction } & \multicolumn{4}{|c|}{$1960-1969(\mathrm{n}=1)$} & \multicolumn{4}{|c|}{$1970-1979(n=23)$} & \multicolumn{4}{|c|}{$1980-1989(n=30)$} & \multicolumn{4}{|c|}{$1990-1999(n=49)$} & \multicolumn{4}{|c|}{2000 - May $2010(\mathrm{n}=36)$} \\
\hline & $\sum$ & $\bar{x}$ & $\mathrm{SD}$ & $\mathrm{CV}$ & $\sum$ & $\bar{x}$ & $\mathrm{SD}$ & $\mathrm{CV}$ & $\sum$ & $\bar{x}$ & $\mathrm{SD}$ & $\mathrm{CV}$ & $\sum$ & $\bar{x}$ & SD & $\mathrm{CV}$ & $\sum$ & $\bar{x}$ & SD & $\mathrm{CV}$ \\
\hline born kittens & 10 & 10 & 0 & 0 & 135 & 5.9 & 6.0 & 100.2 & 197 & 6.6 & 4.4 & 70.5 & 246 & 5.0 & 4.3 & 90.3 & 163 & 4.5 & 3.1 & 68.8 \\
\hline reared kittens & 9 & 9 & 0 & 0 & 98 & 4.3 & 4.3 & 95.9 & 149 & 4.9 & 3.8 & 88.6 & 181 & 3.7 & 2.9 & 82.8 & 110 & 3.1 & 1.8 & 53.1 \\
\hline mortality of kittens & 1 & 1 & 0 & 0 & 37 & 1.6 & 2.1 & 121.4 & 48 & 1.6 & 2.3 & 142.3 & 65 & 1.3 & 2.7 & 208 & 52 & 1.4 & 2.2 & 204.7 \\
\hline number of litters & 10 & 10 & 2 & 0 & 98 & 4.3 & 4.1 & 92.1 & 148 & 4.9 & 3.7 & 79.0 & 197 & 4.0 & 2.8 & 78.3 & 122 & 3.4 & 2.4 & 69.2 \\
\hline mother reared & 0 & 0 & 0 & 0 & 35 & 1,5 & 3.9 & 186.3 & 131 & 4.4 & 3.7 & 110.9 & 119 & 2.4 & 2.5 & 117.9 & 69 & 1.9 & 1.9 & 72.1 \\
\hline hand reared & 0 & 0 & 0 & 0 & 6 & 0.3 & 0.6 & 159.8 & 8 & 0.3 & 1.4 & 199.7 & 60 & 1.2 & 2.5 & 179.8 & 40 & 1,1 & 1.3 & 201.3 \\
\hline 1 young in litter & 10 & 10 & 0 & 0 & 101 & 4.4 & 2.5 & 50.3 & 152 & 5.1 & 8.3 & 130.2 & 165 & 3.4 & 1.9 & 150.8 & 126 & 3.5 & 1.3 & 150.2 \\
\hline twins & 0 & 0 & 0 & 0 & 31 & 1.3 & 1.8 & 121.4 & 43 & 1.4 & 1.2 & 123.7 & 25 & 0.7 & 1.2 & 145.1 & 35 & 0.9 & 1.1 & 105.8 \\
\hline triplets & 0 & 0 & 0 & 0 & 3 & 0.1 & 0.6 & 465.0 & 2 & 0.1 & 0.3 & 355.7 & 54 & 0.8 & 0.4 & 356.4 & 2 & 0.1 & 0.2 & 418.2 \\
\hline quadruplets & 0 & 0 & 0 & 0 & 0 & 0 & 0 & 0 & 0 & 0 & 0 & 0 & 2 & 0.0 & 0.3 & 692.8 & 0 & 0 & 0 & 0 \\
\hline
\end{tabular}

$\overline{\mathrm{X}}$ - mean, $\mathrm{SD}$ - standard deviation, $\mathrm{CV}$ - coefficient of variance, $\mathrm{n}=$ number of females 


\section{Discussion}

In comparing continents the following of births was found: single were most frequent; less frequent twins; infrequent triplets; rarest quadruplets - two sets were born in Zoo Dortmund. As well [5, 6, 17] argue that the number of kittens in a litter can be from one up to four. This implies that the birth of two sets of quadruplets is an exceptionally rare event. According to $[9,10]$.According to results of [12] were born more males than females which agree with our conclusions and hypothesis. When was evaluated the age of females at their first litter by $[13,15]$ the females had their first litter at 18 to 45 months of age. One female from our study had her first litter at1.5 years. Other females had litters later mean in 4.2 years. In the Studbook of ocelots [1] states that the average age for first litter of the ocelot in America was about 4.2 years. Europe had the lowest age of female first birth at 3.4 years and in Asia the highest, 4.7. Our results for America show 4.8 years. The highest number of litters by month occurred in June and August, while the lowest number was in November and December. By [12]kittens were from the middle of April to late December. [4]wrote that ocelots delivered from October to January. Ocelots births observed [20] in the wild in late summer and autumn. These data do not confirm the hypothesis that the ocelots reproduce mostly in the summer months, because the data involved the evaluation of ocelots living in the wild.

\section{Conclusions}

Under captive conditions, their natural survival instincts are in captivity either poorly developed or absent. This fact is reflected in the challenges of educating the young where it becomes necessary to hand rear them. Another reason for the necessity of hand rearing was due to orphaned wild kittens were often found after their mother had been killed or when the parental bond was broken by interactions with people.. showed an increasing trend of reproduction characteristics. From 1960 - 1999 there was an increase in reproductive rates both for ocelots hand reared under captive conditions. Breeding is not threatened but during the last two decades, 1990-2010, this increase in hand rearing has created bond between the humans involved and the animals. Although efforts have been made to obtain unrelated animals, for example from the wild, success can be limited. Despite good management of breeding programs, the mothers often develop a complex of behavior, this may lead to problems of young females subsequently adequately caring for their litters.

\section{Acknowledgements}

Immense "thank you" to the Ocelot SSP chairman Ken Kaemmerer and studbook coordinator for America Mrs.
Nanette Bragin for kindly lending the Studbook of ocelot, Ken Kaemmerer - curator of Mammals at Pittsburgh Zoo \& PPG Aquarium, Ocelot SSP chairman and to all zoological gardens in Europe and Asia, zoos and private breeders in the Czech Republic, for providing the data on reproduction. Many thanks Katherine Madelene Crook for very careful English correction and help with the English text,other people which helps with correct English and the rewievers for comments. This work was supported with MEYS 6046070901 .

\section{REFERENCES}

[1] Bragin N. North American regional Ocelot Studbook2010.

[2] Caso A., Lopez-Gonzalez C., Payan E., Eizirik E., de Oliveira T., Leite-Pitman R., Kelly M. \& Valderrama C. 2008: Leopardus pardalis. In: IUCN 2013. IUCN Red List of Threatened Species.Version2013.1.Downloaded on 04 September 2013.

[3] Cisin C. Pet ocelot. Harry G. Cisin Publisher Amagansett: New York, 1 - 41,1967.

[4] Denis A. Cats of the World. The Riverside Press Cambridge, Cambridge: United Kingdom1964.

[5] De Oliveira T.G. Neotropical Cats: Ecology and Conservation, Sao Luis. Brazil,1994.

[6] De Oliveira T.G. \&Cassaro K. Guia de campo dos felinos do Brasil (online). Instituto Pró-Carnívoros/Fundação Parque Zoológico de São Paulo/Sociedade de Zoológicos do Brasil/Pró-Vida Brasil, São Paulo, Brazil. 2005 (cit 2011-02-10). From $<$ http://www.iucnredlist.org/apps/redlist/details/11509/range map\#>. 2005 .

[7] Eaton R. Why some felids copulate so much. p. 73-94. In: The World's cats: constributions to biology, ecology, behavior and evolution. Carnivore Research Institute. Seattle, Washington. No. 3, 1-179,1976.

[8] Garman A. Ocelot(Leopraduspardalis) [online] Big Cats online. [cit.2007/11/8]. Downladed www.abf90.sila.pipex.co m/bco'/ocelot.htm. 2000.

[9] Haines A.M., Tewes M.E., Laack L.L., Grant W.E. \& Young J. Evaluating recovery strategies for an ocelot (Leopardus pardalis) population in the United States. BiolConserVol.12,No.6,512-522, 2005.

[10] Haines A.M., Tewes M.E., Laack L.L., Horne J.S. \& Young J.H. A habitat-based population variability analysis for ocelots (Leopardus pardalis) in the United States. BiolConserNo. 132, 424-436,2006.

[11] Hines R. 2009: Hand Raising Wild Exotic Cats (Ocelots, Bobcats, Servals, Tigers Etc.). Downloads on 15 June 2011. From http://www.2ndchance.info/ocelot.htm.

[12] Laack L.L., Tewes M.E., Haines A.M. \&Rappole J.H. Reproductive life history of ocelots (Leopardus pardalis) in southern Texas. Acta Theriol. Vol. 50, No.4, 505 514,2005 
[13] Laack L.L. Ecology of the ocelot Felis pardalis in South Texas. (M.S. Thesis). Texas A\&I University, Kingsville, 1991.

[14] Kittel J. "Leopardus pardalis" (On-line), Animal Diversity Web. Accessed May 04, 2012 at http://animaldiversity.ummz.umich.edu/site/accounts/inform ation/Leopardus_pardalis.html.2011.

[15] Mansard P. Ocelot, In: Management guide lines for exotic cats (J. Partridge, eds.). The Association of British Wild Animal Keepers. Bristol: United Kingdom.pp. 92 - 102, 1991.

[16] Mellen J.D. Factory influencing reproductive succes in small captive exotic felids (Felis spp.). A multiple regression analysis. Zoo BiologyNo. 10,95 - 110,1991.

[17] Montgomery L. Ocelot (online). FCF/Feline Conservation Federation. 2011 [2011-01-26]. From $<$ http://www.felinecon servation.org/feline_species/ocelot.htm $>.2011$.
[18] Morais R.N., Mucciolo RG., Gomes M.L.F., Lacerda O., Moraes W., Moreira N., Graham L.H., Swanson W.F. \& Brown J.L. Seasonal analysis of semen characteristics, serum testosterone and fecal androgens in the ocelot (Leopardus pardalis), margay (Leopardus wiedii) and tigrina (Leopardus tigrinius). TherioNo. 57, 2027-2041, 2002.

[19] Nowell K. \& Jackson P. (compilators and eds.) Wild Cats. Status Survey and Conservation Action Plan. IUCN/SSC Cat Specialist Group. IUCN. Gland, Switzerland,1996.

[20] Redford, K.H. \& Eisenberg J.F. Mammals of the Neotropics: the southern cone. University of Chicago Press: Chicago, 1992.

[21] Sunquist, M. and Sunquist, F. Wild Cats of the World. University of Chicago Press.2002.

[22] Veselovský, Z. Vždyt' to jsou jen zvířata, Mladá fronta Praha,246 - 257, 1974. 